\title{
THE EFFECT OF ACTIVATING THE ROLE OF THE AUDIT COMMITTEE ON AUDITOR'S SOUND JUDGMENT ABOUT MATERIAL MISSTATEMENTS: AN EMPIRICAL INVESTIGATION IN EGYPT
}

\author{
Dr. Muhamd Khamis Zaytoun \\ Assistant Professor, Accounting Department, Arab East Colleges, Riyadh, Saudi Arabia \\ DOI: 10.46609/IJSSER.2020.v05i10.023 URL: https://doi.org/10.46609/IJSSER.2020.v05i10.023
}

\begin{abstract}
The present paper aims to experimentally examine and test the effect of activating the role of audit committees as a corporate governance mechanism on the auditor' sound judgment about material misstatements in financial statements in the Egyptian professional practice environment. The current study targets auditors of listed companies. We have chosen arbitrarily a selective sample of 193 auditors, We are used to measuring the effect of activating the role of the audit committee on auditor's sound judgment about material misstatements in financial statements, experimentally designing $(2 \times 1)$, this variable has been divided into two levels (activating the role of the audit committee and not activating the role of the audit committee). A lack of statistically significant differences is found between sample auditors under activating or not activating the role of the audit about auditor's sound judgment regarding material misstatements in the financial statements.
\end{abstract}

Keywords: audit committees, corporate governance, Professional judgment, professional skepticism.

\section{INTRODUCTION}

Professional judgment influences the very essence of auditing; it pervasively is ${ }^{1}$ audit quality from the beginning to the end, and it can be both the primary means by which auditors control non-sampling risk and a major source of it. If evidence, beliefs, and risk assessments are the cornerstones of auditing, professional judgment is their connective mortar (Bell et al. 2005). Focus recently has increased auditor' fundamental sound judgment, because of the move towards principles-based-accounting and auditing standards, and an increased focus on fair value

\footnotetext{
${ }^{1}$ Professional judgment is the application of relevant training, knowledge and experience; within the context provided by auditing, accounting and ethical standards, in making informed decisions about the courses of action that are appropriate in the circumstances of the audit engagement.
} 


\section{International Journal of Social Science and Economic Research}

ISSN: $2455-8834$

Volume:05, Issue:10 "October 2020"

measurements (Mala and Parmod 2015) $)^{2}$.

Several studies (Libby and Luft 1993; Solomon and Shields 1995; Solomon and Trotman 2003; Nelson and Tan 2005) addressed professional judgments, Libby and Luft (1993) have proposed the conceptual equation of the determinants of performance of auditor' judgment based on the results of previous studies in the field of accounting and auditing, and have pointed out that the performance of judgment is a function of both the ability and motivation, environment and knowledge. Nelson and Tan (2005) explained the determinants of auditor' sound judgment in three groups; the first group is related to the task of the auditing, and the second is related to an auditor, the latter is concerned with the relationship between the auditor and other joint parties to perform the task.

On the other hand, audit committee is - a committee of the Board of Directors - one of the most important corporate governance mechanisms that affects the quality of the financial reporting, including the audit quality, and through its interaction with both the auditor and management. The main goal of the composition of audit committees is to confirm and increase the reliability and credibility of the financial statements through its support for the independence of the auditor and help him to perform the audit process without any pressure adversely affecting the credibility or the reliability of the results. Many studies have been conducted in order to explore the relationship between audit committees properties (the independence of the audit committee, and the experience of its members, and the number of its meeting) and audit quality, and many studies (Klein 2002; Abbott et al. 2003; Carcello et al. 2009; Lin and Hwang 2010) have shown that the audit Committee properties increase the effectiveness and the ability of the auditor to reduce earnings management practices, and thus improve the quality of financial reporting. On the contrary, other studies (Felo et al. 2003; Line et al. 2006; Ghosh et al. 2010) did not support the existence of a relationship between audit committee characteristics and earnings management practices.

Since the auditor in charge of clear responsibility for issuing sound professional judgment, and understanding the determinants of judgments safety help in the formulation of solutions that support their safety, and since the purpose of issuing effectively auditor' judgment is to improve the fairness, transparency and reliability of the information contained in the financial statements, which is consistent with the objectives of corporate governance, we give great concern to a clear

\footnotetext{
${ }^{2}$ In the final report of the advisory committee on improvements to financial reporting to the united states securities and exchange commission, issued on august 1, 2008, addressed the use of 'reasonable judgments' in the accounting and auditing profession recognized the need for a cultural shift towards the acceptance of more judgment and recommended that both the SEC and PCAOB issue statements of policy articulating how the reasonableness of accounting and auditing judgments is evaluated.
} 


\section{International Journal of Social Science and Economic Research}

ISSN: $2455-8834$

Volume:05, Issue:10 "October 2020"

vision for a sense of whether and / or how it can contribute to the audit committee as a corporate governance mechanism in the issuance of the auditor's sound professional judgment. Therefore, the present paper aims to experimentally examine and test the effect of activating the role of audit committees on the auditor' sound judgment about material misstatements in financial statements in the Egyptian professional practice environment.

The academic interest of the research comes from its concentration on the importance of the auditor' sound judgment, keeping pace with the auditing standards focus especially the international and US auditing standards (IAASB 2012; APB 2010; APB 2012; PCAOB 2012), which emphasize the importance of the role played by professional judgments in the audit process. The research acquires its professional importance from the role the sound judgment plays in reducing the likelihood of inappropriate auditor's selection or application of the audit procedures and thus, the wrong interpretation of the audit results. In addition to the establishment of IAASB issued new report IAS standards (2014). 720; 700; 701; 570; 705; 706; 260, proposed to be applied starting from December 15, 2016, aiming to renew the auditor's focus on the things that should have been reported, and that increase issuing of professional judgments.

The current paper is organized as follows: In Section 2 the theory and hypotheses are presented. Section 3 discusses the design and results of the experiment and the final section provides conclusions.

\section{THEORY AND HYPOTHESES}

\section{Steps of sound judgment process}

Professional judgment does not mean that the auditor has access to or can configure the conclusions on his own, auditors always issue conclusions on the information and evidence gathered, and also professional judgments do not mean that the auditor is able to detect misstatements that he could not collect information about after applying appropriate audit procedures. Professional judgment is the process of forming an opinion or evaluation characterized in accordance with the professional and ethical standards, which require specialized knowledge and ongoing and extensive training (Fazal 2011). According to some researchers (e.g., Abdul Karim 1991; Morrill 2005; Mahjoub 2012) professional judgments is a process of continuous understanding and recognition to acquire information and run it through the auditing stages, and the purpose of it is choosing an alternative from among the available alternatives in light of the auditor's experience.

Auditors with experience and knowledge can issue, when applying professional standards, various provisions in the same similar circumstances, this does not necessarily mean that a 


\section{International Journal of Social Science and Economic Research}

ISSN: $2455-8834$

Volume:05, Issue:10 "October 2020"

particular judgment is true and the other is wrong, but that results from challenges directed by auditors when issuing professional judgments. Glover et al. (2012) believe that the auditor' unintentional thinking may lead to the issuance of the improper judgment, and therefore auditor must clarify the steps of the judgment process, because they positively contribute to reducing personal bias, gathering information, and drawing diverse perspectives of others.

According to Ranzilla et al. (2013), the document of issuance of judgment is seen as crucial, because it helps to develop well-reasoned conclusions, when others are against these judgments, to show an analysis of the characteristics and circumstances and the alternatives that were taken into account, and to explain how judgment was reached. Therefore many studies and professional organizations (CICA 1995; Ballou and Dan 2004; Moore 2009; ICAS 2012; Glover et al. 2012; Ranzilla et al. 2013; CAQ 2014) focused on clarifying the basic steps for the auditor' sound judgment, and made clear that it is represented in:

- Identifying and defining the issue. This is not always as easy as it sounds, and

it depends on the ability to consider multiple perspectives, including information that contradicts with management's assertions.

- Gathering the facts and information, and identifying the relevant literature.

This is not limited to learning the company's version of events through discussion. Critical assessment of evidence such as contracts, memoranda, calculations, meeting minutes, and external information is also part of the process.

- Performing the analysis and identifying the alternatives. Auditors need to be thorough while examining potential alternatives and they should be vigilant in identifying information that could disconfirm expectations or management's position.

- Making the decision. If a supportable judgment process has not been followed, the auditor might need to reconsider the process and the evidence obtained.

- Reviewing and completing the documentation and rationale for the conclusion. Documentation should be performed throughout the judgment process, as it can enable a more objective and complete assessment.

\section{The auditor' communication with those charged with governance}

Recognizing the importance of effective two-way communication between the auditor and those charged with governance during the auditing process; the International Auditing and Assurance Standards Board has issued IAS 260 which provides a comprehensive framework for the auditor' 


\section{International Journal of Social Science and Economic Research}

ISSN: $2455-8834$

Volume:05, Issue:10 "October 2020"

communication with those charged with governance3, and identifies some specific matters to be communicated with them. The Standard has revealed that effective communication between the parties is considered important in assisting both the auditor and those charged with governance in understanding matters related to the audit in context, and in developing constructive working relationships. This relationship is developed while maintaining the auditor's independence and objectivity (IAS (2015). 260. 4).

According to this standard, the communication between the auditor and those charged with governance is considered an integral part of each audit process, however, the standard did not oblige the auditor to conduct procedures, in particular, to identify the matters that should be concerned, but explained that the auditor should communicate with those charged with governance regarding the scope and timing of the audit planning process, and continues to regard the point of view concerning the nature of significant accounting practice for client, and also to communicate regarding the material limitations faced during the audit. It also identified that the auditor should contact with those charged with governance, writing about independence and in a timely manner, and should be evaluated whether the communication in both directions is considered sufficient for the purpose of the review process or not, and if it was not enough, the auditor should be evaluated according to his assessment of the risks of material misstatements, and his ability to collect adequate and appropriate evidence, and take appropriate actions.

\section{The effect of activating the audit committee's role on auditor's sound judgment about material misstatements}

Some studies (Dechow et al. 1996; Pedro et al. 2005; Aly 2005) interpreted the relationship between audit and corporate governance in general, and the relationship between governance and the prevention and detection of fraud in particular. It could be argued that corporate governance, and its mechanisms, especially the internal control and the board and the management and the audit committee will necessarily affect the audit process starting with the acceptance of the engagement and ending with the auditor's report, passing through all of the planning and execution of audit work (Aly 2005). Dechow et al (1996) showed that the ability of client to commit fraud in the financial statements and the auditor's inability to issue skepticism judgment about it are less likely in companies that have strong audit committees.

Sharma et al (2008) and Ebaid (2011) have concluded that the auditor tends to accept new client

\footnotetext{
${ }^{3}$ Although the auditor is responsible for communicating matters required by this ISA, management also has a responsibility to communicate matters ofgovernance interest to those charged withgovernance. Communication by the auditor does not relieve management of this responsibility. Similarly, communication by management with those charged withgovernance of matters that the auditor is required to communicate does not relieve the auditor of the responsibility to also communicate them. Communication of these mattes by management may, however, affect the form and timing of the auditor's communication with those charged withgovernance (IAS (2015). 260.5).
} 


\section{International Journal of Social Science and Economic Research}

ISSN: $2455-8834$

Volume:05, Issue:10 "October 2020"

when activation of corporate governance mechanisms (the board of and the audit committee) exists rather than when not activated, this happens when the auditor evaluates the strength or weakness of the board and the audit committee, as the board which includes a large proportion of non-executive members from outside the company and who enjoy a high level of financial knowledge and expertise, would make the auditor more favorable to accept the audit process than in the case of the weakness of the board working on their supervisory duties, activation or not activation of the corporate governance mechanisms affect the auditor's judgment when planning the audit process. The independence and the presence of non-executive directors is important in contributing to the improved performance of the client (Huang and Chan 2013) by improving the effectiveness of the audit function (Carcello et al. 2002; Abbott et al. 2003), as they are more objective and more able to uphold the shareholders' interest from their point of view, and to mitigate the behavior of collusion by managers (Upadhyay et al. 2014) and to reduce the possibility of fraud in the financial statements (Beasley 1996) and the earning management (Bruyneels and Cardinaels 2013) and improve financial performance (Daily et al. 2003) and support the auditor's independence in case of disagreements with management (Dezoort and Salterio 2001).

Some studies (Carcello et al. 2002; Abbott et al. 2003; Husnin et al. 2016) argue that the strong corporate governance structures of companies (powerful Committee audit, a balance of power between the management, the board and the owners of the company) demand high quality audit. Experimental evidence has shown that the audit committee plays a vital role because it is responsible for overseeing the process of financial report (Johl et al. 2012) and is able to prevent fraud in the financial statements (Klein 2002). This role is achieved effectively when it increases the number of members of the audit Committee, Al- ajmi (2008) explained that the size of the audit committee is intrinsically linked with its effectiveness. Some studies (Dezoort and Salterio 2001; Robinson and Jackson 2009) interpreted the factors that affect the extent to which the audit Committee plays its role in maintaining the independence of the auditor and supports his judgment. Dezoort and Salterio (2001) and Zhang et al (2007) noticed that the independence of the members of the audit committee and the knowledge and experience of financial reports and audit reports result in supporting the auditor's independence and reducing the pressures of the board on him. Shaheen (2001) also noted the effect of the absence of the company's audit committee on the fairness and credibility of the financial statements and the audit quality. In the same context, Goodwine and Seow (2002) concluded that managers and auditors are aware of the impact of the strength of the audit committee on auditor's sound judgment, through its strengthening to maintain of the auditor's independence, which is also supported by some studies (He et al. 2014; Wilbanks et al. 2015).

In this regard, Sami (2009) confirmed on the role of the audit committee in the activation of 


\section{International Journal of Social Science and Economic Research}

ISSN: $2455-8834$

Volume:05, Issue:10 "October 2020"

corporate governance mechanisms, through the consolidation of the independence of the auditor and maintaining his neutrality, which leads to sound judgment release, thereby increasing the credibility and transparency of the financial statements. Ebaid (2011) explained that the existence of audit committee includes a large proportion of external non-executive members, those with the technical and financial expertise, that would lead to the capability of the audit committee to play their role properly, as reflected by the auditor being more favorable to accept the audit process than the case of the weakness of the audit committee in carrying out supervisory duties optimally. In this regard, Robinson and Jackson (2009) revealed the existence of an inverse relationship between the auditor's change and the characteristics of the audit committee represented in independence, financial expertise, due professional care and expertise with corporate governance, and knowledge for the affairs of the company, they also concentrated on the importance of the independence and expertise of the members of the audit committee to strengthen the independence of the auditor. Taking in consideration the attempts being made to improve the performance of the auditors, Wolosky (2002) recommended the need to delegate power to appoint and determine the auditor's fees to the audit committee.

we can emphasize the importance of taking into account the auditor's concern with the extent of activating or not activating the role of audit committees, because of its effect on the sound of its judgment starting with the acceptance of the audit client, through the assessment of material misstatements, until the release of the auditor for his report, which is consequently reflected on the audit quality. But we believe that previous studies have addressed whether activating the role of audit committees affect the judgment of the auditor but did not address how can audit committees improve and support the auditor's independence, objectivity and the exercise of professional skepticism, which is reflected on the sound of his judgment, so we review some suggestions that could be on the way to support the corporate governance mechanisms of the auditor's performance.

\section{Suggestions for activating the role of the audit committee}

There was always a belief that the Sarbanes-Oxley Act requires the availability of financial experience in the members of the Audit Committee (at least one) (Albring et al. 2014), but this act did not require experience of auditing. Experience of auditing and sufficient depth to audit committee members together can provide an independent assessment of the auditor's options to risk audit and approach used to auditing, and help them to make sure of inspection reports for the PCAOB (Rittenberg 2012). Therefore, expanding the experience of auditing requirement for the audit committee members can be effective in supporting the independence of the auditor and the exercise of professional skepticism (Badolato et al. 2014; Phillips et al. 2015). On the other hand, it can help the audit committee to assess the knowledge of audit team about the business and 


\section{International Journal of Social Science and Economic Research}

ISSN: $2455-8834$

Volume:05, Issue:10 "October 2020"

strategies of the auditee company and the associated risks through discussions and sessions with the partner about how the auditor acquires sufficient understanding of client and its environment, which helps the auditor to exercise appropriate professional skepticism which is reflected in the sound of its judgment ${ }^{4}$.

It could be argued that the audit committee should get a comprehensive understanding of the planed approach to audit, and it should be a meeting between the head of the audit committee and the partner to discuss the general plan for auditing. In addition, the audit committee should be proactive in consulting management and audit team in the controversial accounting issues (Bhattacharjee et al. 2014). On the other hand, the audit committee should be interested to pursue rotate members of the audit team, even if it is the rotating audit partner, and it must know how the audit firm rotates their staff in the various audits and how to contribute in maintaining auditor's professional skepticism (Albring et al. 2014).

On the other hand, the integration of the actual inspection of audit firms and audit committee cycle, and the presence of obliging on the audit committee to understand what of audit firms are doing in their relationship with the inspections, can improve the independence of the auditor and the exercise of professional skepticism; because auditor realizes that the audit committee takes into account the results of the inspection. So audit firms must provide report on the results of inspections of audits conducted to the audit committee, and then the audit committee examines the specified matters in the comments about aspects of the audit deficiencies, and can be assisted by the specialized auditing experience (Albring et al 0.2014).

On the other hand, the current trend to consider the audit committee the audited client makes it the final decisive with respect to continuing or changing the auditor, which supports the independence of the auditor, and is reflected on the issuing of skeptical judgment (Christensen et al. 2015). Glover and Douglas 2014) proposed that the audit committee can formally evaluate the audit firms every few years (generally every five years) by establishing a set of criteria to evaluate the performance of the auditor as part of the process of choosing or changing him, and this helps to focus on the auditor's ability to identify, evaluate and confront the audit risks and exercise appropriate professional skepticism when performing the audit.

we believe that this trend may not be favorite for several reasons, most noticeable one is that if the audit committee does its function, it annually evaluates the auditor, in addition, there may be

\footnotetext{
${ }^{4}$ Knechel et al (2010) showed that the auditors who have developed more complex mental models about client business environment, have made better running for information and issued the more accurate and skeptical judgment when risk assessment. Brewster (2012) showed that both auditors with in-depth understanding, as well as those who have less understood about the client's business operations initially refused incorrect interpretations that they generate about contradictions in the financial statements, however, in a short time (about five minutes) only auditors who have gained a thorough understanding of the client's complex business processes summoned correctly the reasons behind thesecontradictions.
} 


\section{International Journal of Social Science and Economic Research}

ISSN: $2455-8834$

Volume:05, Issue:10 "October 2020"

concerns about the preparation of the report to the public for such a special audit environment characterized by increasing lawsuits, and the responsibility of the audit committee is oversight and should not be mixed with testing the financial statements. Moreover, there could be a bias in the development of standards that are the basis of evaluation of the auditor, they may be defensive in nature for the auditor and, finally, there may be more emphasis on the results of the evaluation process on issues that may not be directly related to the quality of the audit. Instead, the audit committee when evaluating the continuity of the auditor can formally evaluate the auditor based on the meetings to discuss the general plan for auditing, and depending on the submitted report on the matters, he has encountered during the review process, demanding from him to comment on how to maintain its independence and the exercise of professional skepticism, and it helps the audit Committee to have documented and meaningful process.

Based on the above, we conclude that the auditing standards require effective auditor's communication with those charged with governance because of its significant impact on the auditor's sound judgment. In addition, there is a subscription between the auditor and all of the board members and the audit committee to communicating with transparency on their supervisory role, and improving the audit quality. They can overcome the potential threats of independence and the exercise of the auditor's professional skepticism via their cooperation where the audit committee can affect the auditor's professional skepticism through its objective position and its desire to support the role of the auditor when collecting adequate and appropriate evidences, and the party who bears the cost of the audit (management) is not as important as the party responsible for selecting and keeping or changing the auditor (audit Committee) and consequently, the audit committee can support the auditor when exercising professional skepticism, as the audit Committee can elevate culture of professional skepticism by challenging the judgment of both the management and the auditor, and encouraging all parties to examine all the possible evidence (confirm and non- confirm) when sentencing judgment and follows up on whether the auditor has gained enough understanding about the client and its environment, so it can be said that activating the role of audit committees that could affect the integrity of the professional judgment of the auditors, so we will test the following hypothesis:

Hypothesis 1: activating the role of the audit committee positively affects the auditor's sound judgment about material misstatements in the financial statements.

\section{Methods}

\section{Sample selection}

Study is applied on a single population comprised of auditors of the listed companies, we have arbitrarily chosen a selective sample of the population including 193 auditors. Descriptive 
International Journal of Social Science and Economic Research

ISSN: 2455-8834

Volume:05, Issue:10 "October 2020"

statistics for the sample of $s t u d y^{5}$ is shown in table (1) as follows:

Table (1) Descriptive statistics for sample

\begin{tabular}{|l|c|}
\hline \multicolumn{1}{|c|}{ statement } & Sample \\
\hline Qualifications & \\
\hline Bachelor of Accounting & $75.7 \%$ \\
Postgraduate Diploma & $19.2 \%$ \\
Master Accounting & $2.8 \%$ \\
PhD in Accounting & $2.3 \%$ \\
\hline Professional certification: & $84.2 \%$ \\
\hline not get a certificate & $15.8 \%$ \\
received a certificate & \\
\hline Membership and Fellowship professional & \\
\hline associations: & $24.4 \%$ \\
non-member & $75.6 \%$ \\
member & $15.9 \%$ \\
\hline Functional class: & $25 \%$ \\
\hline Juiner & $34.15 \%$ \\
Senier & $25 \%$ \\
Manager or supervisor & \\
Audit partner & $8.4 \%$ \\
\hline Work Experience: & $9.6 \%$ \\
\hline Less than 3 years & $27.5 \%$ \\
From 3 to 5 years & $54.5 \%$ \\
\hline From 5 to 10 years & \\
More than 10 years & 9.08 \\
\hline Experience a specific task: & 77( \\
\hline mean & ] 7.230[ \\
\hline )median( & \\
[standard deviation] &
\end{tabular}

\section{Measurement of variables}

The variables of study comprise the independent variable, which is activating the role of the audit

\footnotetext{
${ }^{5}$ We distributed 627 questionnaires on the sample by manual delivery and social networking sites and personal interviews to auditors in audit firm. After a period ranging from two to fourteen weeks, we received of which 216 questionnaires, up $34.45 \%$ in response, and ruled out a number of them 23 questionnaires because incomplete responses, and so the sound questionnaires was the percentage of received the sound questionnaires $89.4 \%$. Results of the statistical analysis and public data the sound questionnaires showed that the average time it takes to answer the questionnaires was 33.55 minutes a standard deviation of 23.464 minutes.
} 


\section{International Journal of Social Science and Economic Research}

ISSN: $2455-8834$

Volume:05, Issue:10 "October 2020"

committee, and the dependent variable of the auditor's sound judgment about material misstatements in financial statements, misrepresentations, and these variables will be measured and tested for the research's purpose as follows:

Activating the role of the audit committee: we depend on the strong and objective attitude of the audit Committee and its desire to support the independence of the auditor when collecting adequate and appropriate evidence and its awareness of the conduct of the audit process, and to challenge the judgment of the auditor and the management, and its extent provided in support of the auditor where there is disagreement with management about an arguable issue, and their willingness to provide additional fees when performing additional tests or exceeded the time budget. This comes in line with Brazel et al (2013) who measure this variable through a form (zero, one) model where there is a strong demand by those charged with governance and the audit Committee for the performance of a high quality audit process (one), and when there is not a strong demand by those charged with governance and the audit committee of the performance audit process with high quality (zero).

Auditor's sound judgment about material misstatements in financial statements: It means the commitment to professional performance standards to provide reasonable assurance that the area of estimation is in line with the standards and substantially non- interpolated (Knechel et al. 2013), it was measured by the auditor's obligation to follow the steps of sound judgment set by the professional guidelines and previous studies (CICA 1995; Moore 2009; ICAS 2012; Glover et al. 2012; Ranzilla et al. 2013; CAQ 2014), and represented in; identify and clarify the issue and objectives, and collect and evaluate information, and identify and evaluate potential alternatives, and issue of sound judgment, and examine the logic conclusion. We linked auditing standards and the requirements of steps sound judgments, and derived the following sub-scales for measuring the sound of professional judgment of the auditor on material misstatements:

- The first measure of the sound of professional judgment is assessing the reliability of the whole financial statements (Harding and Ken 2011), and auditing standards require that performing the audit require a questionable thinking admitting the possibility of material misstatement (ISA (2015). 200.13.I). We have asked a sample to answer a question in a hypothetical case to determine the degree to approve "that there was no significant misstatements in the financial statements", it was measured using 9-Point Likert scale, starting from 1 = strongly disagree and ending with $9=$ strongly agree, the least degree indicates the safety of professional judgment, which is considered the first step of the process of sound judgments steps, which identifies and clarifies the issue and objectives.

- The second measure of the sound of professional judgment is assessing the validity of 
International Journal of Social Science and Economic Research

ISSN: $2455-8834$

Volume:05, Issue:10 "October 2020"

management's explanations (Quadackers and Tom 2009). Auditing standards require from the auditor to investigate the information provided by the management to him (ISA (2015). 240.A9), and in particular, auditor should know the motive of providing information. We have asked a sample to answer a question in a hypothetical case to determine the percentage of the likelihood that management's explanations provide truthful information on material misstatements, when the percentage decreases, it is a proof of the sound of professional judgment which we considered the second step of the sound judgments process, which is collecting and evaluating information.

- The third measure of the sound of professional judgment is the reliability of the source of audit evidences (evidence provided by management and is subject to its control) (Harding and Ken 2011; Kim and Ken 2015), and in this regard, the audit standards require that the auditor should be skeptical regarding the credibility of financial statements, and that takes into account the possibility of relying on the documents prepared by the management, requiring from him critical evaluation of the audit evidences (ISA (2015). 200.A18). The sample has been asked to answer a question in a hypothetical case to determine the reliability of the evidences provided by the management, it was measured using a 7-Point Likert scale, starts from $1=$ unreliable at all and ends with $7=$ reliable dramatically, the least degree indicates the sound of professional judgment, which is considered the second step in the sound judgment process which is collecting and evaluating information.

- The fourth measure for the sound of professional judgment is a number of alternative explanations provided by the auditor (Quadackers and Tom 2009; Kim and Ken 2015), the auditor is expected to submit sound judgment, that issues the largest reasonable alternative explanations, we asked a sample to answer the question in the default state to choose a number of alternative explanations for the case, the greatest number of alternative explanations indicates the sound of professional judgment, which we considered the third step of the steps of sound judgments, that is the identification and evaluation of potential alternatives.

- The fifth measure for the sound of professional judgment is the number of Counterexplanations (Quadackers and Tom 2009; Kim and Ken 2015), audit standards require from the auditor to perform the audit process with a questionable thinking and critical evaluation of the evidences, it was measured by the number of Counter- explanations provided by the auditor and that assumes that the management's explanations are errorexplanations, the greatest number of Counter- explanations chosen by an auditor refers to Sound Judgment, which we consider the third step of the process of sound judgments, that is the identification and evaluation of potential alternatives .

- The sixth measure for the sound of professional judgment is assessing the likelihood of 


\section{International Journal of Social Science and Economic Research}

ISSN: $2455-8834$

Volume:05, Issue:10 "October 2020"

material misstatements (Harding and Ken 2011; Kim and Ken 2015), the audit standards requires from the auditor to identify, evaluate and respond to the risks of material misstatements (ISA (2015). 315.6.7.8). The auditor's sound professional judgment is the core focus of this study. Sample has been asked in the default state to issue a professional judgment about the likelihood of material misstatements in the financial statements, it has been measured using a 9-Point Likert scale, beginning with $1=$ low likelihood of material misstatements and ending with $9=$ high probability of material misstatements, a high probability refers to the sound of professional judgment, which we considered as representing the fourth step of the process of sound judgments steps, that is the issue of good judgments.

We believe that these sub-scales are a continuous process repeated in more than one step of issuing sound judgment process, the auditor generates alternative explanations when collecting and evaluating information, or when evaluating possible alternatives, or before directly issuing his sound judgment. Due to the researcher's dependence on these measures, we have converted these sub-variables (the reliability of the financial statements, and the validity of explanations of management, and the reliability of the evidences) to the inverse so that all the scales can move in one direction.

\section{Tools and procedures for the empirical study}

We relied on the design of a hypothetical case and presented it to the sample under experiment, and questioned about the opinion of sample regarding the hypothetical case presented to them, and conducted interviews as tools to gather the necessary data to be analyzed statistically to test the hypotheses of research and to answer scientific questions introduced properly.

To conduct the empirical study, we prepared a questionnaire including experimental treatment, and distributed it to the units of the sample, the questionnaire is formed of two parts, the goal of the first section is to get some general data on the sample, and the second section includes the experimental treatment on the subject of the research, The following sections explains the contents of the questionnaire's sections.

Section I: Personal data: this section was targeted to get some basic data about the sample units, as their degrees, their membership or fellowship in professional associations, and professional certificates they have obtained, their functional degrees, and the number of years in their occupation. The question was directed to the sample to determine whether they have registered in the Egyptian financial supervisory authority (EFSA) or not registered, just to determine the number of individuals enrolled in the Egyptian financial supervisory authority (EFSA). 


\section{International Journal of Social Science and Economic Research}

ISSN: $2455-8834$

Volume:05, Issue:10 "October 2020"

Section II: questions about the subject of search: this section contains the hypothetical case6, which includes data on the hypothetical company (abc company) enrolled in the Egyptian Stock Exchange, and is engaged in developing, manufacturing and marketing of pharmaceuticals and medical devices, and consists of three sections (medicine, cosmetics, medical tools department), the audit firm in which units of the sample work audit the financial statements of the company since three years earlier. The company's management is characterized by its favoring to business practices and non-conservative report policies, and focuses on speed and efficiency in the implementation of decisions. Moreover, the company sees the IT department as a necessary evil, and focuses primarily on the achievement of short-term performance measures with only accounting orientation.

we asked units of the sample to assume themselves as being auditors of the company over the performance of analytical procedures to the financial statements, and showed an increase of change in the ratio of gross profit for the current year by $10 \%$ from the previous year, and that this increase is much more than the increases that occurred during the previous five years, and if this increase is not present, the total profit of the company is almost less than disclosed by 15.5 million pounds, (note that the income data were; net sales were 471.7 million pounds, the cost of goods sold 301.7 million pounds, the total profit of 170 million pounds), and although the company's gross profit ratio is always slightly higher than the industry average to which they belong, however, this year, it is higher than the industry average by $32 \%$.

The financial director of the company interprets this increase when the units of the sample asked about by saying that the increase is due to a change in sales matrix in the current year, the sales of the medical tools department is better than before, it has reached $27 \%$ this year compared to the previous year which was $13 \%$, the financial director of the company explained that the sales of the department of medical tools and products price anywhere ranges between more than 10 thousand pounds to more than one million pounds in some cases, knowing that the average selling department of medical tools company products price was 53 thousand pounds only, achieving a gross profit ratio exceeding 45\%. Moreover, the company is more qualified to meet consumer's needs, compared to its competitors, and customers appreciate that.

It is worth mentioning that the hypothetical case took two forms (and thus there were two questionnaires representing two treatments for the hypothetical case) based on the additional information associated with it and that serves the purpose of the research, the first form has included additional information on activating the role of the audit committee, and the second of which provided additional information about not activating the role of the audit committee.

The aim of the design of the hypothetical case as such is providing a sample with a range of

${ }^{6}$ The source of this case is the study (Quackers and Tom 2009) with some action. 


\section{International Journal of Social Science and Economic Research}

ISSN: $2455-8834$

Volume:05, Issue:10 "October 2020"

information regarding the possible existence of material misstatements in the company, is to increase the percentage of gross profit for the current year from previous years, and to provide information representing the managerial interpretation represented by the chief financial officer, as a reason for this increase, it is a change in sales matrix, we rely on this information when answering a series of subsequent questions, which aim to measure the dependent variable, in order to determine whether there is a relationship between the activating role of audit Committee and the sound of the of the auditor's judgement on the material misstatements in financial statements.

The first question has targeted measuring sub-dependent variable assessing the possibility of depending on the financial documents as a whole, while the second question has targeted measuring both; sub-dependent variable assessing the validity of management's interpretations, sub-dependent variable the number of alternative explanations provided by the auditor, and the sub- dependent variable the number of Counter- explanations provided by the auditor, and the third question was targeted to measure sub- dependent variable reliance on the source of audit evidences, and the fourth question was targeted to measure the sub-dependent variable assessing the likelihood of material misstatements.

\section{Experimental design}

We used to measure the effect of the independent variable, activating the role of the audit committee, on auditor's sound judgment about material misstatements in financial statements, experimentally designing $(2 \times 1)$, this variable has been divided into two levels (activating the role of the audit committee and not activating the role of the audit committee). Hence, this experiment contains two experimental treatments, and in the following manner:

The first treatment: The auditor's sound judgment about material misstatements in light of activating the role of the audit committee.

The second treatment: The auditor's sound judgment about material misstatements in light of absence of the activation of the role of the audit committee.

We will make a comparison between the first treatment and the second treatment. This comparison aims to measure the effect of activating the role of the audit committee on auditor's sound judgment about material misstatements, and then testing the hypothesis of the research.

\section{Statistical tests}

We used the Mann-Whitney test to independent samples to conduct comparison and measure the difference between the two independent samples. Due to the researcher's usage of ordinal scales 


\section{International Journal of Social Science and Economic Research}

ISSN: $2455-8834$

Volume:05, Issue:10 "October 2020"

to assemble necessary data to test the hypothesis of the research (Azam, 1990), it was used for comparison between the two sets of experiment to test the hypothesis of the research, and in this case the formulation of the statistical hypothesis is as follows:

H0: M1 = M2 there are no statistically significant differences between the samples of the auditor's sound judgment about material misstatements in light of activating the role of the audit committee and in the absence of activating the role of the audit committee.

H1: $\mathrm{M} 1 \neq \mathrm{M} 2$ there are statistically significant differences between the samples of the auditor's sound judgment about material misstatements in light of activating the role of the audit committee and in the absence of activating the role of the audit committee.

\section{Statistical analysis and results}

The results of the statistical analysis, as shown in the table (3), indicate the level of dependent sub-variables, that P.Value was less than $5 \%$ of the responses of a sample of auditors in light of activating or not activating the role of the audit committee on some of the questions used to measure the dependent variable (assessing the validity of management's explanations, generating Counter- explanations), and it points to the presence of statistical significant differences between samples of the auditors in light of activating or not activating the role of the audit committee about auditor's sound judgment regarding material misstatements in the financial statements. On the other hand, the P.Value is greater than $5 \%$ of the responses of a sample of auditors in light of activating or not activating the role of the audit committee on the rest of the questions used in measuring the dependent variable, and it points to a lack of statistically significant differences between sample of auditors under activating or not activating the role of the audit about auditor's sound judgment regarding material misstatements in the financial statements. Moreover, by reference to the mean rank, we find that the mean rank for the sample auditors in light of activating the role of the audit committee was greater than the mean rank for a sample of auditors in the absence of activating the role of the audit committee. 
International Journal of Social Science and Economic Research

ISSN: 2455-8834

Volume:05, Issue:10 "October 2020"

Table (3)

The results of the statistical analysis of the effect of activating the role of the audit committee on auditor's sound judgment about material misstatements

\begin{tabular}{|l|c|c|}
\hline \multirow{2}{*}{ Statements } & \multicolumn{2}{c|}{ Results of the statistical analysis } \\
\cline { 2 - 3 } & Assmp. Sig. (2-tailed) & $\mathrm{Z}$ \\
\hline $\begin{array}{l}\text { 1- assessing the reliability of the whole Financial } \\
\text { Statements }\end{array}$ & 0.247 & -1.157 \\
\hline $\begin{array}{l}\text { 2- assessing the validity of management's } \\
\text { explanations }\end{array}$ & 0.001 & -3.216 \\
\hline 3-the reliability of the source of audit evidences & 0.568 & -0.572 \\
\hline 4-a number of alternative explanations & 0.405 & -0.833 \\
\hline 5-the number of Counter- explanations & 0.24 & -2.253 \\
\hline 6-assessing the likelihood of material misstatements & 0.781 & -0.287 \\
\hline 7-sound judgment about material misstatements & 0.872 & -0.162 \\
\hline
\end{tabular}

Concerning the overall level of the dependent variable: sound judgment on material misstatements, The results of the statistical analysis showed that P.value was greater than 5\% of the responses of a sample of auditors in light of activating or not activating the role of the audit committee, and it points to a lack of significant differences between samples of the auditors in light of activating or not activating the role of the audit committee about auditor's sound judgment on material misstatements in the financial statements.

Based on the results of this comparison, it is clear that there were no statistically significant differences between the samples of the auditors in light of activating or not activating the role of the audit committee about auditor's sound judgment on material misstatements in the financial statements. Even though there are significant differences between the samples of auditors in light of activating or not activating the role of the audit committee on their judgments when assessing the validity of management's explanations, however, that did not affect the judgment on the reliability of the financial statements or evidences provided by the management or even the number of alternative explanations provided by the auditors on the change in the proportion of the total net profit. However there was a significant difference in the number of Counterexplanations provided by the auditors to issue sound judgment, which refers to the increase in the independence and accuracy judgment of auditors when activating the role of the audit committee, but that was not reflected in the judgment of the auditor when assessing the material misstatements in financial statements, the auditor's assessment did not differ in light of activating the role of the audit committee compared with the absence of activating the role of the audit committee. Based on these results, we cannot refuse $\mathrm{H} 0$, and thus rejecting the alternative 


\section{International Journal of Social Science and Economic Research}

ISSN: $2455-8834$

Volume:05, Issue:10 "October 2020"

hypothesis, meaning the lack of statistically significant differences between the samples of the auditors in light of activating or not activating the role of the audit committee on auditor's sound judgment about material misstatements. Therefore the hypothesis of the current research is rejected.

\section{Conclusions and Limitations}

We aim to experimentally examine and test the effect of activating the role of audit committees as a corporate governance mechanism on the auditor' sound judgment about material misstatements in financial statements in the Egyptian professional practice environment. According to the findings, there is a lack of statistically significant differences between sample auditors under activating or not activating the role of the audit about auditor's sound judgment on material misstatements in the financial statements.

The results of this hypothesis is inconsistent with the study of Soliman and Mohamed (2013) which argues that the audit committee role of oversight is a clear signal of the expectations placed upon the auditor to perform high-quality audit procedures, and that the proportion of nonexecutive directors has a significant positive impact on the auditor' sound judgment, and thus the audit quality, because they encourage effective auditing as part of their oversight role to reduce the agency costs, and that the independence of the members of the audit committee is intrinsically linked with the auditor' sound judgment. The results of this hypothesis came in line with the study of Khalil and Ozkan (2016) which argues that an increase in the number of non- executive directors on the audit committee may not be enough to restrain earnings management, or quality audit achievement, due to the ownership levels of shareholders and senior managers. Which is available in the Egyptian environment through the spread of the family business pattern.

we suggest the need for in-depth experience for the audit committee members (one of its members specializing in auditing, not accounting only) to conduct an independent assessment of the auditor's procedures, and follow-up inspection reports of audit firm, and the need of the audit committee to formally assesses the facilities of the accounting and the audit firms every few years and the report on that assessment, through the development of criteria for evaluating the performance of the auditor, which helps it to focus on the commitment to audit standards and professional ethics and standards of quality control, and to exercise the sufficient professional skepticism and follow sound judgments steps in the process of performing audit, which is reflected in auditor's sound judgment about material misstatements in the financial statements.

These results provide empirical evidence on activating the role of the audit committee in the professional Egyptian practice environment, which is evident through; the strong and objective position of the audit committee and its need to support the independence of the auditor when 


\section{International Journal of Social Science and Economic Research}

ISSN: $2455-8834$

Volume:05, Issue:10 "October 2020"

collecting adequate and appropriate evidences, and supporting him through the consciousness of how the audit process is conducted, and to challenge his own judgments and the management ones, and the audit Committee providing him with significant support when there are disagreements between him and the management on the dialectic issue, and its willingness to provide additional fees in the case of exceeding the time budget or the performance of additional tests, if necessary, meaning a strong demand from those responsible for governance for performing high quality audit process.

This does not affect auditor's sound judgment about material misstatements in the financial statements.

The present research has a number of limitations that should be taken in consideration: other variables other than the activation of the role of the audit committee may affect the integrity of professional judgment of the auditor's. Both of thesefactors have been attributed to the auditor or the audit client or professional practice environment. Also beyond the scope of research, other professional judgments other than professional judgment on material misstatements in the financial statements, such as going concern, analytical procedures and other professional judgments should be considered in future research.

\section{References}

Abdul Karim, A. A. 1991. The Impact of the Auditor's Personal Judgment on the Results of Statistical Inference in the Auditing. Unpublished PhD Thesis, Faculty of Commerce, Tanta University.

Albring, S., D. Robinson, and M. Robinson. 2014. Audit Committee Financial Expertise, Corporate Governance, and the Voluntary Switch from Auditor-Provided to Non-AuditorProvided Tax Services. Advances in Accounting. 30(1): 81-94.

Aly, A. W. 2005. Mechanisms of Positive Governance Role of New Report by the Auditor. Conference on Corporate Governance, Faculty of Commerce, Alexandria University.

Auditing Practices Board (APB). 2010. Auditor Skepticism: Raising the Bar. Discussion paper, APB.

\section{- 2012. Professional Scepticism Establishing A Common Understanding and} Reaffirming its Central Role in Delivering Audit Quality. APB

Badolato, P. G., D. C. Donelson, and M. Ege. 2014. Audit Committee Financial Expertise and Earnings Management: The Role of Status. Journal of Accounting and Economics. 58(2): 208-230. 
International Journal of Social Science and Economic Research

ISSN: 2455-8834

Volume:05, Issue:10 "October 2020"

Ballou, B., and D. L. Heitger. 2004. Judgment and Decision- Making Research in A Dynamic Auditing Environment. Working Paper, Auburn University.

Bell, T. B., M. E. Peecher, and I. Solomon. 2005. The 21st Century Public Company Audit. New York, NY: KPMG LLP.

Bhattacharjee, S., K. K. Moreno and J. S. Pyzoha. 2014. The Influence of Audit Committee Intervention Approach on Auditor and Client Judgments During Accounting Disputes. Northeastern U. D'Amore-McKim School of Business Research Paper.

Brazel, J. F., S. B. Jackson., T. J. Schaefer, and B. W. Stewart. 2013. Hindsight Bias and Professional Skepticism: Does the End Justify the Means?. Working Paper presented at the 7th EARNet Symposium in Trier, Germany.

Brewster, B. E. 2012. An Experimental Investigation of Delayed Persuasion During Analytical Procedures: Are Auditors Susceptible to the Sleeper Effect? Working paper, The University of Texas at Arlington.

Canadian Institute of Chartered Accountants (CICA). 1995. Professional Judgment and the Auditor. Toronto. Canada.

Center for Audit Quality (CAQ). 2014. Professional Judgment Resource. Available at: http://www.thecaq.org

Christensen, B. E., T. C. Omer., M. K. Shelley, and P. A. Wong. 2015. Audit Committee Influence on Audit Firm Selection, Retention, Efficiency, and Fees. Retention, Efficiency, and Fees. Available at: http://papers.ssrn.com

Dechow , P . M ., R. G . Sloan, and A . P Sweeney . 1996. Causes and Consequences of Earnings Manipulation : An Analysis of Firms Subject to Enforcement Actions By the Sec. Contemporary Accounting Research. 13 ( spring ) : pp 1 - 36

DeZoort, T., and S. Salterio. 2001. The Effects of Corporate Governance Experience and Financial Reporting and Audit Knowledge of Audit Committee Members Judgments. Auditing: A Journal of Practice \& Theory 20 (2): 31-47.

Ebaid, El-Sayed I. 2011. Corporate Governance Practices and Auditor's Client Acceptance Decision: Empirical Evidence from Egypt. Corporate Governance: The international journal of business in society. 11(2): 171-183.

Fazal, H. 2011. How Professional Judgment and Professional Skepticism are Different in 
International Journal of Social Science and Economic Research

ISSN: 2455-8834

Volume:05, Issue:10 "October 2020"

Application? Available at: http://pakaccountants.com.

Glover, S. M., and D.F. Prawitt. 2014. Practitioner Summary: Enhancing Auditor Professional Skepticism: The Professional Skepticism Continuum. Current Issues in Auditing 8 (2): 1-10.

Glover, S. M., D.F. Prawitt and KPMG LLP. 2012. Enhancing Board Oversight: Avoiding Judgment Traps and Biases. Research Commissioned by Committee of Sponsoring Organizations of the Treadway Commission (COSO).

Goodwin, J., and J. L. Seow. 2002. The Influence of Corporate Governance Mechanisms on The Quality of Financial Reporting and Auditing: Perceptions of Auditors and Directors in Singapore. Accounting and Finance. 42(3): 195-223.

Harding, N., and K. T. Trotman. 2011. Enhancing Professional Skepticism via the Fraud Brainstorming Discussion Outcomes. Working Paper, The University of New South Wales.

He, X., J. Pittman., O. M. Rui, and D. Wu. 2014. Do Social Ties between External Auditors and Audit Committee Members Affect Audit Quality?. Working Paper, Shanghai University of Finance and Economics.

Kim, S., and K. T. Trotman. 2015. The Comparative Effect of Process and Outcome Accountability in Enhancing Professional Scepticism. Accounting \& Finance. 55(4): 10151040.

Knechel, W. R., G. V. Krishnan., M. Pevzner., L. B. Shefchik, and U. K. Velury. 2013. Audit Quality: Insights from the Academic Literature. Auditing: A Journal of Practice \& Theory. 32(1): 385-421.

Knechel, W. R., S. E. Salterio, and N. Kochetova-Kozloski. 2010. The Effect of Benchmarked Performance Measures and Strategic Analysis on Auditors' Risk Assessments and Mental Models. Accounting, Organizations and Society 35(3): 316- 333.

Libby, R., and J. Luft 1993. Determinants of Judgment Performance in Accounting Settings: Ability, Knowledge, Motivation, and Environment. Accounting, Organizations and Society. 18(5): 425-450.

Institute of Chartered Accountants of Scotland (ICAS). 2012. A Professional Judgment Framework for Financial Reporting. An International Guide for Preparers, Auditors, Regulators and Standard Setters.

International Auditing and Assurance Standards Board (IAASB). 2012. Professional 
International Journal of Social Science and Economic Research

ISSN: 2455-8834

Volume:05, Issue:10 "October 2020"

Skepticism in an Audit of Financial Statements. IAASB Staff Questions and Answers. New York, NY: IFAC.

International Auditing and Assurance Standards Board (IAASB). 2015. International standards of auditing (ISA) No. 240. The Auditor's Responsibilities Relating to Fraud in an Audit of Financial Statements. New York, NY: IFAC.

. 2015.International standards of auditing (ISA) No. 260. Communication with Those Charged with Governance. New York, NY: IFAC.

- 2015.International standards of auditing (ISA) No. 200. Overall Objectives of the Independent Auditor and the Conduct of an Audit in Accordance with International Standards on Auditing. New York, NY: IFAC.

- 2015.International standards of auditing (ISA) No. 315. Identifying and Assessing the Risk of Material Misstatement through Understanding the Entity and Its Environment. New York, NY: IFAC

Mahjoub, M. O. 2012. The Proposed Framework for the Development of the Role of International Auditing Standards to Streamline the Auditor's Personal Judgment. Scientific Journal of Economy and Commerce. 3(3):1053-1093.

Mala, R., and P. Chand. 2015. Judgment and Decision-Making Research in Auditing and Accounting: Future Research Implications of Person, Task, and Environment Perspective. Accounting Perspectives. 14(1): 1-50.

Moore, G. 2009. Using Professional Judgment. The Auditor Report 33:(1). Available at: http://aaahq.org

Morrill, J. 2005. Professional Judgment and Departures from GAAP: Judgment in Jeopardy Revisited. Canadian Accounting Perspectives. 4(2): 285-299.

Nelson, M. and H. T. Tan. 2005. Judgment and Decision Making Research in Auditing: A Task, Person, and Interpersonal Interaction Perspective. Auditing: A Journal of Practice \& Theory 24(1): 41-71.

Pedro Sánchez Ballesta, J., and E. García-Meca. 2005. Audit Qualifications and Corporate Governance in Spanish Listed Firms. Managerial Auditing Journal. 20(7): 725-738.

Phillips, J. R., K. Jollineau, and S. Jane. 2015. Are Judgments About Auditor Liability 
International Journal of Social Science and Economic Research

ISSN: 2455-8834

Volume:05, Issue:10 "October 2020"

Influenced by Audit Committee Expertise and Independence? Available at: http://papers.ssrn.com

Public Company Accounting Oversight Board (PCAOB). 2012. Maintaining and Applying

Professional Skepticism in Audits. Staff Audit Practice Alert No.10. Washington, DC: PCAOB.

Quadackers, L., T. Groot, and A. Wright. 2009. Auditors' Skeptical Characteristics and Their

Relationship to Skeptical Judgments and Decisions. Working paper.

http://papers.ssrn.com/sol3/papers.cfm?abstract_id=1478105

Ranzilla, S., R. Chevalier., G. Herrmann., S. Glover, and D. Prawitt. 2013. Elevating Professional Judgment in Auditing and Accounting: The KPMG Professional Judgment Framework. New York, NY: KPMG LLP.

Rittenberg, L. E. 2012. Comments on Governance, Professional Skepticism, and Auditor Independence. Working paper.

Robinson, D. R., and L. A. Owens-Jackson. 2009. Audit Committee Characteristics and Auditor Changes. Academy of Accounting and Financial Studies Journal. 13: 117- 132.

Sami, M. 2009. The Role of Audit Committees in Corporate Governance and Its Impact on the Quality of Financial Statements Published in the Egyptian Business Environment. Journal of the Faculty of Commerce Research.46(2):171-213.

Shaheen, A. H. 2001. Analysis of Theory and Practice in the Field of Auditing in the Egyptian Environment with Field Study Problems. Journal of New Horizons. 13(2):11-90.

Sharma, D. S., E. F. Boo, and V. D. Sharma. 2008. The Impact of Non-Mandatory Corporate Governance on Auditors' Client Acceptance, Risk and Planning Judgments. Accounting and Business Research. 38(2): 105-120.

Soliman, M., and M. A. Elsalam. 2013. Corporate Governance Practices and Audit Quality: An Empirical Study of the Listed Companies in Egypt. Available at: http://papers.ssrn.com

Solomon, I., and M. D. Shields. 1995. Judgment and decision research in auditing. In Judgment and Decision Making Research in Accounting and Auditing, eds. R. H. Ashton and A. H. Ashton, 137-75. New York: Cambridge University Press

—., and K. T. Trotman. 2003. Experimental Judgment and Decision Research in Auditing:25 The first 25 years of AOS. Accounting, Organizations and Society. 28 (4): 395- 
International Journal of Social Science and Economic Research

ISSN: 2455-8834

Volume:05, Issue:10 "October 2020"

412.

Wilbanks, R. M., D. R. Hermanson, and V. D. Sharma. 2015. Audit Committee Oversight of Fraud Risk: The Role of Social Ties and Governance Characteristics. Working Paper, Kennesaw State University.

Wolsoky, H. W. 2002. Guide to Oversight and Corporate Reform Law. Practical Accountant. Sep:26-33.

Zhang, Y., J. Zhou, and N. Zhou. 2007. Audit Committee Quality, Auditor Independence, and Internal Control Weaknesses. Journal of accounting and public policy. 26(3): 300-327. 